\title{
A LÍNGUA ESPANHOLA COMO FERRAMENTA PARA PRÁTICA DA EDUCAÇÃO AMBIENTAL
}

\author{
Luana Montagner Pires Penteado ', Marcelo Barcellos da Rosa² \\ ${ }^{1}$ Especialista em Educação Ambiental \\ 2 Professor do Curso de Especialização em Educação Ambiental da UFSM
}

\section{RESUMO}

O ensino da língua espanhola pode ser pensado como uma possível ferramenta interdisciplinar para efetivação de uma constante em educação ambiental. Considerando que a língua espanhola é uma das línguas mais faladas na atualidade e que a sua utilização permite, tanto novas formas de aprendizado, quanto a promoção de uma educação menos fragmentada, o presente trabalho busca, à luz da língua espanhola como meio ou vetor, uma sensibilização das questões ambientais na realidade escolar. $O$ presente trabalho foi desenvolvido realizando-se um levantamento bibliográfico reflexivo, onde foi considerada a relevância da linguagem como mediadora da comunicação humana. Além disso, alunos de 6a e 8a séries do Instituto Estadual de Educação Tiarajú do município de São Sepé - RS trabalharam um material didático em espanhol envolvendo a identidade terrena do aluno sob a perspectiva do meio ambiente e sua preservação. Portanto, procurou-se aguçar a reflexão dos educandos sobre os problemas ambientais que observam em suas vidas e quais possíveis ações que deveriam ser praticadas no processo de amenização do impacto que o ser humano causa ao meio ambiente. $O$ trabalho mostrou que o ensino da educação ambiental precisa ser recorrente a uma prática/rotina educativa, ou seja, deve ser incorporada como uma ação cotidiana, além de sinalizar que a língua espanhola pode contribuir para isso, discutindo e refletindo as atitudes e valores ambientais da sociedade. Assim, pode-se observar que os alunos reconhecem a influência humana sobre o meio ambiente, no entanto carecem de ações que facilitem o processo, tanto de internalização, quanto de prática propriamente dita da educação ambiental.

Palavras-chaves: língua espanhola, educação ambiental, interdisciplinaridade.

\section{ABSTRACT}

The teaching of Spanish language can be thought as a possible and effective interdisciplinary tool in the practice of the environmental education. If we consider the Spanish as one of the most widely spoken languages in the news and that its use allows both new forms of learning and the promotion of education less fragmented, the present work, in the light of the Spanish language as a means or vector, an awareness of environmental issues in the school. This work was carried out by performing a literature reflective, which was considered the relevance of language as a mediator of human communication. In addition, students at 6 th and 8th grades of the State Institute of Education Tiarajú from São Sepe - RS worked a material in Spanish involving earthly identity of the student's perspective of the environment and its preservation. Therefore, we tried to sharpen the thinking of students about the environmental problems they see in their lives and what possible actions that should be applied in the process of softening the impact humans are having on the environment. The study showed that the teaching of environmental education to be an applicant to practice or routine education, or be incorporated as a routine action and advise that the Spanish language can 
contribute to it, discussing and reflecting the attitudes and environmental values society. Thus, we can see that students recognize the human impact on the environment, but require actions to facilitate the process, the internalization, much of the actual execution of environmental education.

Key-words: Spanish language, environmental education, interdisciplinary.

\section{INTRODUÇÃO}

Com tantas alterações ambientais que ameaçam comprometer a qualidade de vida no planeta Terra e as grandes desigualdades sociais e econômicas entre os países, a Educação Ambiental tornouse uma alternativa prática e viável à maioria das sociedades que desejam a solução ou pelo menos, a amenização destes problemas. Nas últimas décadas, o acentuado desenvolvimento industrial e urbanização causaram uma devasta exploração dos recursos naturais do Planeta que, antes de ocorrer os primeiros acidentes ambientais, eram vistos como fontes inesgotáveis.

À medida que parte da sociedade mundial começou a preocupar-se com a conscientização da necessidade de conservação do meio ambiente, os estudos que buscam garantir a sustentabilidade do lugar em que vivemos precisam ser divulgados e incentivados, principalmente, por meio da educação ambiental.

Dentro deste contexto, trabalhar a educação ambiental numa perspectiva interdisciplinar, por meio da língua espanhola, é uma possibilidade que precisa ser incentivada, como forma de evidenciar o comprometimento conjunto de uma escola com a mitigação dos problemas ambientais.

Buscando superar a fragmentação do saber em diversas "gavetas" que dificultam uma visão mais ampla da crise ambiental que vivenciamos, o ensino interdisciplinar surge como um possível caminho. O ensino interdisciplinar por diversas razões, ainda está sendo enfatizado de forma modesta na prática educativa nas escolas. No entanto, a proposição de um projeto interdisciplinar que favoreça a formação de uma "pedagogia ambiental", apresentando uma "integração responsável" pela atitude ecologicamente correta, das diferentes áreas do conhecimento, promoveria maior motivação dos estudantes pelo assunto.

A língua espanhola é, na atualidade, uma das línguas mais faladas no mundo e além de se aproximar bastante com a língua portuguesa, devido a mesma raiz de origem de ambas, ainda conta com a proximidade dos países de origem hispânica com nossa fronteira, permitindo que os brasileiros tenham uma maior familiaridade e compreensão desta. Isso contribui de maneira significativa no processo de ensino/aprendizagem do espanhol na rede educacional.

Por ser uma disciplina que há pouco tempo começou a fazer parte do currículo das escolas estaduais, a língua espanhola apresenta-se como instigadora da curiosidade. Foi inserida no currículo escolar pela possibilidade de oferecer outra língua estrangeira aos educandos e pelos esforços governamentais dos países integrantes do Mercosul como forma de integrar as diferentes culturas. Por isso, seu ensino possibilita uma maior oportunidade de tornar-se relevante, ainda mais se abordar assuntos de interesse público e atuais como as dificuldades na preservação de um meio ambiente saudável.

Desta forma, o presente trabalho propõe uma reflexão sobre a importância da preservação do meio ambiente realizando um trabalho interdisciplinar que integre o ensino do espanhol e a educação ambiental, visando refletir sobre a crise ambiental que se vivencia e, assim, promover a transformação em cidadãos conscientes e engajados com a sustentabilidade do planeta. 


\section{A comunicação humana}

A comunicação é fundamental em qualquer contexto para a sociedade e é imprescindível para o ato de educar em sala de aula, uma vez que todas as informações e conhecimentos são transmitidos no momento em que se efetua a comunicação. Para que esta ocorra, são necessários alguns aspectos como emissão e recepção da informação entre emissor e receptor.

De acordo com Santos (2005, p. 437-438) o termo comunicação designa "o estabelecimento de entendimento, de compreensão, o compartilhamento de idéias, pensamentos e sentimentos comuns". Não necessariamente a comunicação pode ser somente verbal, mas também engloba aspectos não-verbais que são utilizados no ato de comunicar para que a mensagem seja compreendida pelo receptor como o uso de sinais, símbolos, etc.

\section{A comunicação humana por meio da linguagem}

A ação educativa, como já foi citado anteriormente, concretiza-se através da comunicação fomentada por meio da linguagem. A língua portuguesa, que é a língua oficial no Brasil, assim como o espanhol, o italiano, o romeno, o francês e o catalão são denominadas de línguas românicas ou latinas, pois pertencem a um grupo de idiomas que se originaram a partir da evolução do latim, em especial do latim vulgar utilizado pelas classes populares (WIKIPÉDIA, 2010).

Como o presente trabalho busca fomentar a discussão acerca da questão de como a Língua Espanhola como ferramenta na sensibilização da Educação Ambiental, faz-se necessário uma pequena contextualização histórica à luz de como se encontra a situação do ensino do espanhol no sistema educacional brasileiro.

\section{Contextualização histórica}

Em março de 1991 foi assinado o Tratado de Assunção que consolidou o Mercado Comum do Sul (Mercosul), entre o Brasil, Argentina, Uruguai e Paraguai. Em 1996, Chile e Bolívia passaram a ser países integrantes da associação.

O Mercosul foi estabelecido com a intenção principal de integrar tais países, facilitando entre eles a livre circulação de bens, serviços, capitais, pessoas e a promoção do desenvolvimento científico-tecnológico que permeia as economias.

Os princípios norteadores do Mercosul, dentre os pontos acordados afirmaram que a educação deve agir como processo e aspecto fundamental para que os objetivos do Tratado sejam desenvolvidos e mantidos, onde um dos principais objetivos deste seria o de possibilitar um relacionamento harmônico entre os países envolvidos através da aprendizagem de ambas as línguas no ensino formal.

Alguns princípios foram acordados, entre eles, na área da educação, ficando estabelecidos:

"Que a educação tem um papel fundamental para que esta integração se consolide; Que a educação depende, em grande parte, da capacidade dos países latino-americanos de reencontrar seus valores comuns e de afirmar sua identidade ante os desafios do mundo contemporâneo; O interesse de difundir o aprendizado dos idiomas oficiais do Mercosul, espanhol e português, através dos sistemas educacionais formais, não formais e informais; $A$ necessidade de garantir um nível adequado de escolarização, assegurando uma educação básica para todos, respeitadas as características culturais e lingüísticas dos Estados Membros; A necessidade de estimular maior integração entre educação-trabalho-emprego; Tornar os 
sistemas escolares compatíveis e harmônicos, para que o ensino seja equivalente nos quatro países". (Princípios do Mercosul, 1991)

Portanto, observa-se que um dos pontos cruciais do Tratado entre os países é a aprendizagem do espanhol como segunda língua, onde a proximidade lingüística e geográfica de tais países favorece a comunicação e estreita os laços econômicos e culturais.

O Plano Trienal para Educação no Mercosul foi aprovado em 1992 e estabeleceu algumas medidas para o ensino das línguas oficiais do Tratado, sendo esta a de implementar o ensino de português e espanhol em diferentes níveis e modalidades do sistema educacional a fim de oportunizar uma comunicação com uma menor barreira lingüística possível entre os países membros.

Em relação à educação brasileira, esta é regida pela Lei de Diretrizes e Bases da Educação Nacional (LDB), de dezembro de 1996, que, em seu artigo 36, inciso III, contempla a inclusão de uma língua estrangeira moderna, de caráter obrigatório e escolhida pela comunidade.

Atualmente, o espanhol passou a ter maior destaque no sistema educacional brasileiro e mundial, onde se encontra entre as cinco línguas mais faladas mundialmente (WIKIPÉDIA, 2010).

Em termos dos Parâmetros Curriculares Nacionais (PCN's), de 1998, esses destacam que o ensino de uma língua estrangeira oportuniza ao educando expandir sua "percepção como ser humano e como cidadão" (p. 63). Assim, o aluno tem a possibilidade de compreender como cidadão a responsabilidade que possui com o mundo e o quanto pode intervir nele e não deixando de lado a realidade em que está inserido. Além disso, os PCN's enfatizam que o ensino de uma língua estrangeira deve abordar temas transversais como meio ambiente, ética, saúde, orientação sexual, trabalho, consumo e pluralidade cultural, já que possibilitam que a aprendizagem de línguas traga "a compreensão das várias maneiras de se viver a experiência humana" (p. 63). Dessa forma, evidenciase a necessidade de contemplar o meio em que se vive no contexto escolar.

Trazendo para a realidade da região central do Estado do Rio Grande do Sul, como é o caso do Instituto Estadual de Educação Tiaraju, localizado no município de São Sepé - RS, a língua espanhola tem como objetivo proporcionar ao educando condições para que perceba a sua importância como vínculo de comunicação internacional, de modo que ocorram práticas de estruturas fundamentais dessa língua e o domínio de um vocabulário que permita ler e compreender textos, assim como conseqüência uma comunicação globalizada.

Nesse sentido, o ensino do espanhol possibilita um amplo meio de discussão dos mais variados temas, já que visa a ampliação do vocabulário dos educandos uma vez que promove meios para que a comunicação ocorra, tanto ao se deslocarem para algum dos países que possuam como língua oficial, bem como para a comunicação através dos recursos tecnológicos atualmente usados como a Internet.

A educação e em específico da língua espanhola pode, portanto, promover este intercâmbio entre diferentes culturas partindo de informações disponibilizadas em sala de aula. Como se sabe, o processo de educar transcende a questão do apenas transmitir conhecimentos, pois proporciona a transformação das pessoas, uma vez que o ambiente escolar busca a formação dos cidadãos, conforme destacam os PCN's e as LDB.

Assim, busca-se com o ensino da língua espanhola, além de formar indivíduos que contemplem a realidade, que entendam e possuam a capacidade para criticá-la conscientemente, que se preocupem com a coletividade e que consigam atuar perante os obstáculos no mundo.

Em relação a figura do educador em sala de aula, este deve contribuir para a formação do senso crítico do educando. Portanto, o educador deve estar sempre sintonizado com uma formação 
que fomente a discussão sobre a realidade e que deste modo, para que cada um possa estabelecer o que é ideal e correto para si.

\section{Educação ambiental}

A educação ambiental consiste em um processo de transformação cultural e de quebra de paradigmas sócio-econômico-culturais em que uma mudança na concepção do ser humano em relação ao meio ambiente deve ser trabalhada e revista, já que a degradação ambiental pode ser agravada, se o quadro de crise ambiental não for mitigado.

Luzzi (2005, p. 381) explicita ao apontar que “é um problema enraizado na cultura, nos estilos de pensamento, nos valores, nos pressupostos epistemológicos e no conhecimento, que configuram o sistema político, econômico e social em que vivemos". Nesse sentido, a crise ambiental que se vê na atualidade transpassa o desenvolvimento econômico e apossou-se do meio ambiente sem qualquer preocupação com sua preservação.

Ao falar sobre meio ambiente, é corriqueiro que se associe a questões como natureza, vida biológica, flora e fauna (CARVALHO, 2004). Entretanto, parece que o ser humano que faz parte desse meio ambiente não está inserido nesse contexto e transparecendo até mesmo que existe um mundo natural que se contrapõe à vida humana. Daí surge a pergunta, de como pode existir uma separação se é no meio ambiente em que todas as espécies convivem?

Mediante a uma tradição naturalista, é que a Educação Ambiental emerge e procura ultrapassá-la com fundamento na visão socioambiental onde se requer um empenho de superação entre o paradigma natureza e da sociedade (CARVALHO, 2004). Somente com a superação dessa visão naturalista é que se pode contemplar o meio ambiente em sua totalidade, ou seja, integrando a espécie humana à natureza.

Para Carvalho (2004, p. 37) a visão socioambiental

orienta-se por uma racionalidade complexa e interdisciplinar e pensa o meio ambiente não como sinônimo de natureza intocada, mas como um campo de interações entre a cultura, a sociedade e a base física e biológica dos processos vitais, no qual todos os termos dessa relação se modificam dinâmica e mutuamente.

Dessa forma, a visão socioambiental considera o meio ambiente como espaço relacional, onde a espécie humana, não apenas aquela que é intrusa e dominadora, mas que também pertence "à teia de relações da vida social, natural e cultural e interage com ela" (p. 37).

Contextualizando historicamente, entre as décadas de 60 e 70 é que os problemas ambientais começam a emergir e colocando em voga a questão ambiental. Em Roma, em 1968, uma reunião foi realizada com cientistas dos países desenvolvidos para discutir sobre o crescimento da população, o consumo e as reservas de recursos naturais não renováveis, processos ambientais gerados pela ação antrópica.

A Organização das Nações Unidas (ONU) realizou em 1972, em Estocolmo, na Suécia, a primeira Conferência Internacional sobre Meio Ambiente e Desenvolvimento.

Em 1975 foi promovida em Belgrado (atual Sérvia), uma reunião de especialistas em educação, onde se definiram os objetivos da Educação Ambiental, publicados no que se convencionou chamar "A Carta de Belgrado", em Tbilisi. Na Geórgia, em 1977, realizou-se o primeiro Congresso Mundial de Educação Ambiental. 
No Brasil, é na década de 70 que surgem as primeiras ações e movimentos que se intitulam ambientais ou ecológicos. O governo, nessa mesma época, direcionou-se para a regulação, legislação e controle das questões ambientais (CARVALHO, 2004).

A Rio-92 que aconteceu no Rio de Janeiro, sendo a segunda Conferência das Nações Unidas sobre Meio Ambiente e Desenvolvimento.

Nessa ocasião, os movimentos ambientais e as Organizações não-governamentais (ONG's) de todo o planeta elaboraram o Tratado de Educação Ambiental para Sociedades Sustentáveis e Responsabilidade Global, a Agenda 21, que aponta princípios e um plano de ações para educadores ambientais, "estabelecendo uma relação entre as políticas públicas de educação ambiental e a sustentabilidade" e tratando principalmente da reorientação da educação ambiental no ensino formal (Jacobi, 2003: 194).

Portanto, é na Rio 92 que surge o conceito de sustentabilidade como aponta Jacobi (2003, p. 195) que na compreensão de desenvolvimento sustentável, de forma mais ampla, remete a que sejam novamente definidas as relações entre a natureza e o ser humano, reportando a um novo processo do desenvolvimento humano e social, por meio de um repensar de suas ações. Para o autor, a idéia de sustentabilidade

implica a prevalência da premissa de que é preciso definir limites às possibilidades de crescimento e delinear um conjunto de iniciativas que levem em conta a existência de interlocutores e participantes sociais relevantes e ativos por meio de práticas educativas e de um processo de diálogo informado, o que reforça um sentimento de co-responsabilidade e de constituição de valores éticos. Isto também implica que uma política de desenvolvimento para uma sociedade sustentável não pode ignorar nem as dimensões culturais, nem as relações de poder existentes e muito menos o reconhecimento das limitações ecológicas, sob pena de apenas manter um padrão predatório de desenvolvimento (JACOBI, 2003, p. 195).

Nessa concepção, vislumbra-se a preocupação de que todos os cidadãos sejam responsáveis pelos problemas ambientais provenientes da ação antrópica, bem como sejam eles conscientes também que suas atividades são nocivas ao meio ambiente. É necessário uma tomada de atitudes diferenciada para que se alcance a tão desejada sustentabilidade do planeta e que a existência das gerações futuras não sejam comprometidas.

A educação ambiental pode contribuir para que isso seja alcançado, pois pode ser definida como um processo que direciona as pessoas a uma compreensão crítica e global do meio ambiente. Busca proporcionar a possibilidade de adquirir conhecimentos, valores e desenvolver atitudes, que permitam desenvolver ações para conservar e proteger o meio ambiente.

Para tanto, é muito importante que a Educação Ambiental esteja cada vez mais presente na vida da sociedade humana e que esta seja predominante nas ações diárias das pessoas, promovendo o repensar de suas ações, induzindo-as a se comprometer com o desenvolvimento sustentável, uma vez que a educação tem o poder de transformar as pessoas, podendo até mesmo mudar o mundo.

Baseando-se neste breve histórico sobre a trajetória da Educação Ambiental, pode-se vislumbrar o longo caminho que vem sendo traçado para que se faça compreender por todos os cidadãos que possuem em suas mãos as ferramentas para o comprometimento com a busca do desenvolvimento sustentável do planeta.

A Educação Ambiental, no Brasil, orienta-se, portanto, pelo Tratado firmado na Rio 92 e tem procurado criar uma visão interdisciplinar para melhor entender os aspectos que envolvem as relações entre o ser humano e o meio em que vive para interferir nelas (CARVALHO, 2004).

Nesse sentido, a Educação Ambiental defende a não fragmentação do saber. 


\section{Interdisciplinaridade e afins}

Atualmente o termo interdisciplinaridade está muito em voga dentro do contexto escolar, pois se acredita que é capaz de solucionar ou amenizar os problemas existentes dentro da prática educacional no que se refere à aprendizagem.

Mesmo que seja muito citada, parece que seu significado não está bem claro, ou ainda modestamente discutido no contexto educacional, o que pode desfavorecer sua prática em sala de aula. Mas, devido aos diversos estudos já realizados, sua importância é comprovada como recurso teórico-metodológico na prática educacional.

De acordo com Coimbra (2000, p. 54), o termo interdisciplinaridade "apresenta-se despretensioso na sua origem, ambíguo na sua acepção corrente e complexo na sua aplicação", o que confirma a apreensão e à grande dificuldade encontrada pelos docentes para compreendê-la e colocá-la em prática.

O vocábulo é citado por vários autores, as discussões realizadas por Carvalho (2004), Coimbra (2000) e Santomé apud Marques (2005) merecem nossa atenção.

Primeiramente, faz-se necessário a conceituação do termo que se deve pela sua formação, resultado da união do prefixo inter, do sufixo dade ao substantivo disciplina, na perspectiva de Assumpção (1996, p. 23)

[...] inter, prefixo latino, que significa posição ou ação intermediária, reciprocidade, interação [...] dade (ou idade) sufixo latino guarda a propriedade de substantivar alguns adjetivos, atribuindo-Ihes o sentido de ação ou resultado de ação, qualidade, estado ou, ainda, modo de ser. Já a palavra disciplina [...] ordem que convém ao funcionamento duma organização ou ainda um regime de ordem imposta ou livremente consentida[...].

Para Carvalho (2004) a interdisciplinaridade não tem a intenção de unificar os saberes, porém almeja a existência de um espaço de troca entre os conhecimentos, onde as disciplinas configuram uma mútua cooperação para a criação de um ponto comum na compreensão da complexa realidade.

Já Coimbra (2000, p. 56), o vocábulo arraiga um vínculo "não apenas entre saberes, mas, principalmente, de um saber com outro saber, ou dos saberes entre si, numa sorte de complementaridade, de cumplicidade solidária, em função da realidade estudada e conhecida". Essa cumplicidade não anula a existência de cada disciplina, onde cada uma conserva a sua identidade, mantém sua metodologia e contempla os seus respectivos limites de cada área.

O que resulta disso são outros afins como a multidisciplinaridade, pluridisciplinaridade e transdisciplinaridade. Tais acepções variam conforme diferentes fontes.

A idéia de multidisciplinar, conforme Coimbra (2000) atende a um aspecto quantitativo, com várias disciplinas, sem estabelecer vínculo entre as abordagens, ou seja, um mesmo assunto pode ser tratado por duas ou mais disciplinas sem que haja um diálogo entre elas e seus agentes. Cada uma segue abordando seu tema com seus critérios unidisciplinares.

Já a pluridisciplinaridade, para Santomé apud Marques (2005), é a justaposição de áreas do saber mais ou menos próximas, em uma mesma seção de conhecimento. Essa justaposição melhora as relações entre ambas as disciplinas, mas reside basicamente na troca de informações, favorecendo a um acúmulo de conhecimento. 
O conceito de transdisciplinaridade é considerado pelo mesmo autor como o nível superior da interdisciplinaridade, onde os limites entre as disciplinas somem e se constitui um sistema total que ultrapassa o plano das relações e interações entre tais disciplinas.

Para Coimbra (2000), o transdisciplinar avança para além da interdisciplinaridade na abordagem de um tema ou objeto. Isso acarreta em uma maior qualidade, uma auto-superação capaz de incorporar à própria formação conhecimentos e saber diferenciados. O que para Carvalho (2004) denota o desaparecimento das disciplinas envolvidas no estudo, na pretensão de um saber comum cabível de ser aplicado a qualquer fenômeno.

Jacobi (2003, p. 34) trata, tanto a pluridisciplinaridade como a multidisciplinaridade como um aglomerar de disciplinas, porém a fragmentação e a justaposição entre elas são mantidas. Para o autor, ao serem vistas como "partes justapostas, colocadas umas junto às outras, a totalidade resume-se à integração e junção do conjunto das partes (disciplinas)". Vislumbra-se, dessa forma, que as disciplinas ainda seguem fragmentadas, isoladas não buscando uma interação entre as diferentes áreas do conhecimento.

A transdisciplinaridade, na concepção do mesmo autor que destaca que esta se origina da disciplinaridade, áreas do saber delimitadas, no entanto, sugere uma maior flexibilidade, podendo uma disciplina misturar-se em outra, denotando movimento por meio das disciplinas.

\section{METODOLOGIA}

Foi realizada uma pesquisa bibliográfica reflexiva sobre a importância da linguagem para a efetivação da comunicação humana, sobre a questão da interdisciplinaridade e sobre a inserção da língua espanhola na realidade curricular brasileira.

Além disso, foi trabalhado e analisado um texto que procura resgatar a importância de uma "postura ecológica" diante das alterações que vem sofrendo nosso meio ambiente.

A prática educativa foi realizada com educandos da 6a série e $8^{a}$ série do Ensino Fundamental no Instituto Estadual de Educação Tiaraju no município de São Sepé, durante as aulas da Língua Espanhola no período de novembro e dezembro de 2009.

A escola trabalha com o curso regular de ensino fundamental, ensino médio - curso normal (antigo magistério) e EJA - Educação de Jovens e Adultos. Os cursos são oferecidos nos turnos matutino, vespertino e noturno e atenderam cerca de 700 educandos no ano de 2009. Embora a escola esteja situada na região central da cidade, a maioria dos educandos provém da periferia e pertencem a classe sócio-econômica de baixo poder aquisitivo, considerando que muitas famílias recebem incentivo financeiro do governo federal (Bolsa Família). Esta consiste em uma ajuda financeira do Governo Federal às famílias pobres, definidas como aquelas que a renda per capita varia de $\mathrm{R} \$ 70,01$ até 140,00 e extremamente pobres com renda per capita até $\mathrm{R} \$ 70,00$. As famílias beneficiárias devem manter seus filhos e/ou dependentes vacinados e freqüentando a escola.

A pesquisa deste trabalho envolveu a interpretação do texto para duas turmas de sexta série e duas de oitava, totalizando 93 participantes. A faixa etária dos educandos da 6a série variou de 11 a 20 anos e da $8^{a}$ série oscilou de 13 a 18 anos. As turmas caracterizam-se por serem mescladas, onde as principais diferenças encontraram-se no fato de que algumas turmas são compostas por educandos regularmente enquadrados dentro da faixa etária sugerida para a série que freqüentavam, além de turmas com a presença majoritária de repetentes e que não fogem do perfil socioeconômico da escola.

A proposta de trabalho foi desenvolvida conforme as seguintes etapas: 
- Etapa 1: leitura do texto oral em conjunto com os educandos.

- Etapa 2: discussão sobre o vocabulário que o mesmo apresentava, na prerrogativa de sanar quaisquer dúvidas que pudessem ofuscar a sua compreensão, que tinha como objetivo promover a reflexão sobre o meio ambiente e sua preservação. Optou-se por trabalhar com o mesmo texto para as distintas séries para tentar observar se o nível de escolaridade influenciaria as respostas, fato que se tornou irrelevante no momento da discussão dos resultados.

- Etapa 3: Solicitou-se aos educandos que respondessem, em duplas, as perguntas de acordo com o texto e com o conhecimento de mundo que possuíam, sendo de livre escolha o uso da língua espanhola ou portuguesa. Cabe ressaltar que a proposta do texto era sensibilizar, em relação a questão ambiental, observando a visão dos mesmos diante desse tema que já vem sendo discutido, em algumas disciplinas, há algum tempo na escola.

\section{RESULTADOS E DISCUSSÃO}

A educação é um aspecto intrínseco na organização das sociedades, sendo um dos fatores que a afeta é, notadamente, a construção da personalidade dos cidadãos. Assim, a escola contribui na moldagem das condutas da espécie humana em sociedade, até mesmo, o caráter individual do que julga ser certo ou errado.

Analisando a importância da linguagem para a efetivação da comunicação humana, constatase, com base na pesquisa bibliográfica reflexiva feita, que as ramificações do latim estreitam laços lingüísticos entre as línguas românicas e o Mercosul colabora para a relevância da aprendizagem da língua espanhola, que passou a ser integrada ao ensino formal e regular da educação básica do Brasil.

Considerando o processo interdisciplinar no âmbito escolar, observa-se uma vagarosa, mas existente valorização da educação ambiental quando utilizada a língua espanhola como vetor na disseminação desta temática, visto sua importância no contexto da comunicação global.

Em relação ao ensino do espanhol e a legislação que regulamenta a educação, evidencia-se o espanhol como possibilidade de uma língua estrangeira que pode expor e trabalhar diversas temáticas, ao mesmo tempo que busca a ampliação do vocabulário dos educandos para a integração de diferentes culturas.

A pesquisa naturalística ou qualitativa na visão de Bogdan \& Biklen apud Lüdke \& André (1986) inclui alcançar dados que sejam descritivos e que tenha a preocupação de demonstrar as perspectivas de seus informantes. Para Minayo (1994), a pesquisa qualitativa parte de um problema, dúvida ou pergunta, considerando conhecimentos que já existem da mesma forma que possam gerar novas referências.

Tratando-se especificamente deste trabalho, levou-se em conta principalmente o conhecimento que os educandos possuem sobre os problemas ambientais enfrentados e possíveis soluções para que sejam amenizados em nível local de abrangência, ou seja, seu bairro, ou proximidades da realidade vivida no cotidiano do educando.

Para que pudesse haver um maior liberdade de expressão, optou-se por desenvolver com os educandos um texto que abordasse um assunto mais abrangente dentro do campo ambiental para que os mesmos pudessem exemplificar com aspectos que observam dentro de cada uma das realidades sócio-econômico-culturais vividas diariamente. 


\section{Surgimento da crise ecológica e para que preservar o meio ambiente}

Analisando as respostas obtidas pelos educandos em relação ao surgimento da crise ecológica:

- $50 \%$ deles atribuíram o seu surgimento ao homem como o responsável, seja por poluição, desmatamento ou queimadas;

- $35 \%$ atribuíram à humanidade e ao uso desmedido dos recursos naturais, tais como se apresentavam no texto;

- $15 \%$ contestaram que era "devido ao comprometimento ambiental", como cita o aluno X de forma equivocada.

A maioria dos educandos reconhece que é o ser humano o grande responsável pela crise ambiental que se instalou, no entanto a minoria parece ter confundido 0 termo "comprometimento", pois se comprometer, segundo o dicionário Houaiss (2004) entende-se como "dar como garantia moral; empenhar; obrigar-se por compromisso" e de maneira inadequada foi empregado por educandos da $8^{a}$ série, pois justamente o que se busca é o comprometimento da população em contribuir com o meio ambiente. Essa observação pode vir a sinalizar até uma questão de analfabetismo funcional que provém de uma estrutura sócio-econômica complexa.

Na seqüência do questionário, quanto a questão do por que devemos realmente preservar o meio ambiente:

- $30 \%$ dos educandos afirmaram que se tratava de uma questão de "necessidade de sobrevivência na terra";

- $15 \%$ atribuíram ao futuro, como diz o aluno Y "Para o futuro do ser humano e de todas as outras espécies que dependem do equilíbrio do meio ambiente".

Outros aspectos foram também citados, como para a respiração, água e natureza, normalizar o clima, equilíbrio ambiental, aumento dos temporais e clima mais quente. Além disso, $10 \%$ dos educandos acreditam que devemos preservar "para que o mundo não acabe" (aluno X).

Isso demonstra que todos admitem que algo deve ser feito para que os efeitos da crise ambiental sejam amenizados, colocando em voga os preceitos do desenvolvimento sustentável, que almeja o equilíbrio entre o desenvolvimento socioeconômico e a preservação do meio ambiente.

O termo "desenvolvimento sustentável" por natureza é bastante amplo e inclui aspectos sociais, econômicos e ambientais, sendo expresso no Relatório Brundtland como o "desenvolvimento que atende às necessidades do presente, sem comprometer a capacidade de as futuras gerações atenderem às suas próprias necessidades".

\section{A interdependência entre a natureza e o homem}

Os educandos relataram que dependemos da natureza para sobreviver porque a necessitamos para comer, respirar e beber. $\mathrm{O}$ aluno $\mathrm{Y}$ diz o seguinte "o homem depende da natureza para tudo, principalmente do que a gente necessita para sobreviver" como também o aluno W responde "o homem não entende que se ele destruir a natureza ele não vai ter onde viver". Dessa forma, a maior parte dos educandos (60\%) relataram que a dependência humana em relação a natureza é muito grande principalmente para a sobrevivência.

Compreende-se, portanto, que os educandos possuem a consciência de que sem o meio ambiente não poderão existir subsídios para a vida humana. Segundo Capra (1995) um novo paradigma é incorporado, onde toma a realidade de forma distinta do modelo que até então era concebido, de partes fragmentadas a uma visão oposta, que se denomina uma visão de mundo 
holística ou ecológica, que compreende o mundo como um todo interligado, com a integração de todos os fatores e seres que fazem parte deste conglomerado que é o meio ambiente. Além disso, somente a partir desse ponto de vista, que é o sistêmico, que poderá ocorrer a garantia de soluções para esta crise em busca da sustentabilidade, ponto-chave para o ideal ecológico, de suprir necessidades atuais sem prejudicar as gerações futuras.

\section{Sinais da natureza e preocupação local na preservação do meio ambiente}

O texto afirmava que a natureza vem dando sinais à espécie humana de que requer cuidados e foi solicitado que os educandos citassem alguns exemplos. Os mais citados foram:

- as enchentes (50\%),

- os temporais (25\%),

- a elevação da temperatura (20\%) e

- os terremotos (5\%).

Também citaram os furacões, os tsunamis, a mortandade de abelhas por envenenamento, as estiagens, a extinção de animais, o efeito estufa, os tornados e a falta de água.

Observou-se que os educandos estão atentos às demonstrações de "revolta" da natureza e que muito evidente apresentam-se no cotidiano das pessoas, às vezes mais amenas e de outras tão avassaladoras que acabam com a vida de milhares de cidadãos, como também deixando muitos desamparados.

Quanto à preocupação em preservar o meio ambiente na localidade em que residem, 40\% deles afirmaram que "nenhuma ou não há preocupação". Outros relataram que cuidam do lixo separando ou reciclando e que possuem rede de esgoto canalizado e que economizam água em casa.

Um fator preocupante pode ser observado na falta de atitude que almeje preservar o meio ambiente. Quase $40 \%$ dos educandos afirmaram que não existe nenhum cuidado, como coloca o aluno X: "Nenhum, pois as pessoas nem estão aí para o meio ambiente", quando visualizam o descaso que ocorre na região onde habitam. Isso demonstra que a população necessita mais informações para que estejam cientes da realidade ambiental e mudem o comportamento que estão apresentando nos dias de hoje.

O artigo 225 da Constituição da República Federativa do Brasil, expõe sobre direitos e deveres dos cidadãos quanto à preservação do meio ambiente ao colocar que

\footnotetext{
"Todos têm direito ao meio ambiente ecologicamente equilibrado, bem de uso comum do povo e essencial à sadia qualidade de vida, impondo-se ao Poder Público e à coletividade o dever de defendê-lo e preservá-lo para as presentes e futuras gerações". (Constituição da República Federativa do Brasil, 1988)
}

Assim, a população tem reservado a si o direito de viver em um ambiente harmônico, mas também incumbe a ela o dever de defendê-lo e conservá-lo. No entanto, o relato da maioria dos educandos mostra que na localidade que residem, as pessoas estão desconsiderando este artigo ao se descomprometerem com a questão ambiental e não colaborarem com a sua preservação, tanto para as atuais como para as próximas gerações.

Como irão preservar e ter um meio ambiente ecologicamente equilibrado, se demonstram não possuir atitudes preservacionistas em relação a ele? Luzzi (2005) explicita que o século atual começa imerso a uma situação crítica socioambiental, que deverá agravar-se se a degradação atual se manter, ou seja, as pessoas devem reconhecer e participar de ações que colaborem para que o ser 
humano estanque sua influência avassaladora sobre o ambiente, compreendendo que seu papel é de co-habitante e não de dominador.

\section{Problemas ambientais locais e atitudes ambientais ideais}

Em relação aos problemas ambientais mais destacados pelos educandos para a cidade de São Sepé, aparecem:

- o lixo jogado nas ruas e a poluição de rios (40\%);

- o desmatamento (30\%) e;

- as queimadas e esgotos a céu aberto (15\%).

Outros exemplos são as queimadas de lixo, impureza do ar, elevação da temperatura, poluição emitida pelos carros, enchentes e falta de água.

As atitudes citadas pelos educandos e consideradas as mais relevantes e que devem ser incorporadas no cotidiano, são:

- não poluir os rios (50\%);

- não desmatar (40\%);

- deixar as ruas limpas (25\%);

- jogar lixo no lixo (20\%);

- parar com as queimadas (10\%);

- reduzir o desperdício de água (10\%) e;

- cuidar do lixo (10\%).

Outras atitudes foram citadas, por exemplo, que indústrias deveriam poluir menos, reduzindo a emissão de $\mathrm{CO}_{2}$; não deixando água parada, comprando madeira legal e regulando os carros para poluírem menos.

\section{O papel da educação ambiental na formação de um ser humano em sintonia com a natureza}

Para Morin (1993 apud BARROS et al, 2006), é apropriado pensar em educação ambiental em sua aprendizagem, utilizando-se do seguinte eixo, expresso em três categorias:

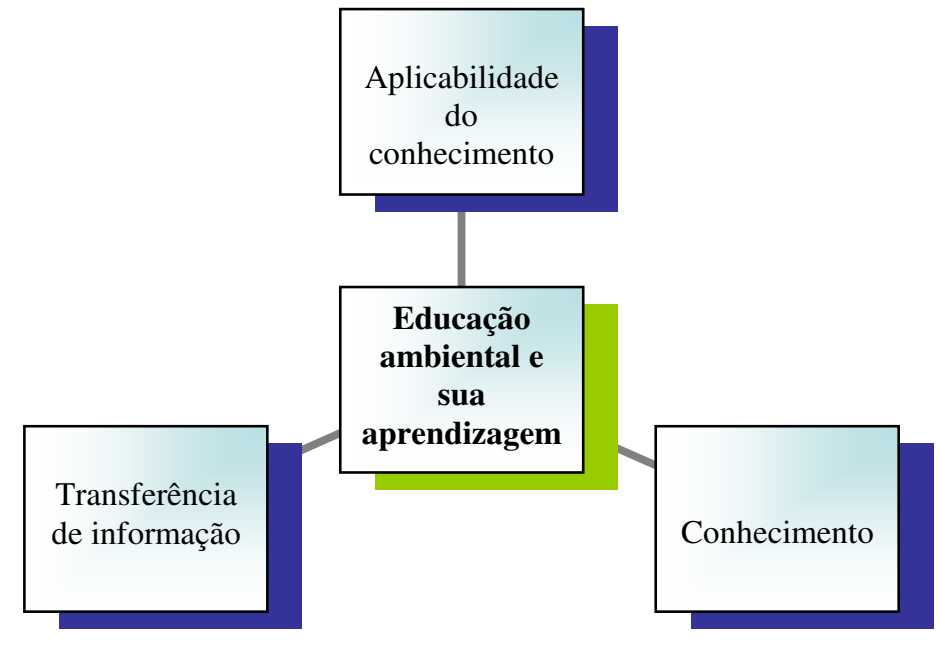


Dessa maneira, a educação ambiental pode compor-se em uma relação coerente e ética com o meio ambiente, onde o cidadão aplica o conhecimento adquirido em prol do planeta por meio de uma ação consciente e cidadã.

Nesse sentido, ao perceber que muitos problemas ambientais são facilmente vistos, os educandos fazendo uso do eixo de aprendizagem proposto por Morin (1993 apud BARROS et al, 2006), podem contribuir com a questão ambiental e atuar conscientemente no cotidiano, aplicando as atitudes que os mesmos julgam importantes para preservar o meio ambiente em sua comunidade.

\section{CONSIDERAÇÕES FINAIS}

- É inegável que a questão ambiental precisa ser introduzida na prática educativa, seja ela em qual disciplina for, considerando-se que deva ser aplicada à medida que for possível ser abordada em sala de aula;

- Este trabalho evidencia que o ensino de uma língua estrangeira, neste caso a espanhola, pode ser utilizado como uma ferramenta aplicável com sucesso no processo de sensibilização da educação ambiental por meio de um trabalho interdisciplinar;

- Acredita-se que, uma vez levando-se em conta a necessidade em se amplificar a internalização dos problemas ambientais pelas sociedades, a escola desempenha e se torna mediadora desse processo, estimulando a reflexão sobre a importância de preservar o meio ambiente tão desgastado pela ação do homem na busca de seu desenvolvimento socioeconômico;

- Os educandos, em sua maioria, reconheceram que o homem tem sua parcela de culpa no surgimento da crise ecológica, caracterizando-o como responsável;

- Existe um reconhecimento por parte dos educandos de que algo deve ser feito pelos cidadãos para reverter este quadro ou tentar amenizá-lo;

- Outrora, a aparente consciência ecológica que demonstraram, parece ser algo refutável, pois, se por um lado se preocupam com o meio ambiente, por outro, a sua aplicação está distante de ser uma rotina;

- Necessita-se que o modelo atual educativo passe a incorporar, em sua prática escolar, conceitos e valores que estabeleçam mais informações acerca do desenvolvimento sustentável e do que é a educação ambiental, para se revogar a noção de ser apenas lixo, água, fauna e flora;

- A educação ambiental precisa ser um tema recorrente na vida humana, seja por acesso ao conhecimento através de um meio formal e/ou informal;

- Aliada ao contexto escolar, a educação ambiental pode atingir as mais diferentes classes sociais em seus mais diversos assuntos e diferentes estratégias, seja através de música, texto, vídeo, jornal, entre outros;

- A prática interdisciplinar pode ser um grande trunfo aos educadores que queiram se engajar na causa ambiental. Resta saber o quanto a desfragmentação do saber no contexto escolar será colocada em prática, pois alguns professores julgam que sua disciplina não pode nem deve se relacionar com outros saberes;

- Fica registrado que os problemas ambientais estão cada vez mais evidentes e é inegável que se deve começar por nós, educadores, essa transformação. 
- Este trabalho qualifica-se como importante, pois se constatou que um trabalho interdisciplinar necessita antes de tudo, de humildade e sensibilidade de quem o propõe. Humildade para reconhecer que o educador possui limitações para conduzir os educandos ao conhecimento da realidade que os cerca e, sensibilidade para compreender que sua disciplina não é exclusiva e nem mais importante que as demais.

- A educação deve permanecer em constante adequação, reformulando-se e viabilizando novos hábitos para que uma sociedade mais justa e equitativa passe a prevalecer. No entanto, a educação não deve ser entendida como a única e responsável para a resolução dos problemas existentes, porém é, sem dúvida, um dos caminhos a se percorrer para que uma sociedade evolua.

\section{REFERÊNCIAS BIBLIOGRÁFICAS}

ASSUMPÇÃO, I. Interdisciplinaridade: uma tentativa de compreensão do fenômeno. In: FAZENDA, I. (Org.) Práticas Interdisciplinares na Escola. 2. ed. São Paulo: Cortez, 1993. 147p.

BARROS , J. C. L. et al. O Direito e a Educação Ambiental como instrumento de reação ao controle externo do patrimônio ambiental natural brasileiro. In: Revista Núcleo de Pesquisa Interdisciplinar NPI. São Manoel, 10 de maio de 2006. Disponível em: http://www.fmr.edu.br/npi/011.pdf Acesso em fevereiro de 2010.

BRASIL. Secretaria de Educação Fundamental. Parâmetros curriculares nacionais: terceiro e quarto ciclos do ensino fundamental: introdução aos parâmetros curriculares nacionais. Brasília: MEC/SEF, 1998. $174 \mathrm{p}$.

CAPRA, F. A Teia da Vida: Uma Nova Compreensão Científica dos Sistemas Vivos. São Paulo: Cultrix, 1995.

CARVALHO, I. C. de M. Educação Ambiental: a formação do sujeito ecológico. São Paulo: Cortez, 2004. 254 p.

COIMBRA J. Á. A. Considerações sobre a Interdisciplinaridade In: A. PHILIPPI Jr.; TUCCI, C. E. M.; HOGAN, D. J.; NAVEGANTES, R. Interdisciplinaridade em Ciências Ambientais. São Paulo: Signus Editora, p. $52-70,2000$.

HOUAISS, A. (Org.) Minidicionário Houaiss da língua portuguesa. 2 ed. Rio de Janeiro: Objetiva, 2004.

JACOBI, P. Educação Ambiental, Cidadania e Sustentabilidade. In: Cadernos de Pesquisa, n. 118, p. 189 - 205, março de 2003.

. Educação e meio ambiente - transformando as práticas. In: Revista Brasileira de

Educação Ambiental, v.:il, n. 0 (nov.2004). Brasília: Rede Brasileira de Educação Ambiental, 2004. 140 p. 


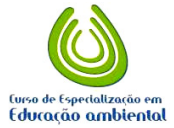

REMOA

LDB - Lei de Diretrizes e Bases da Educação Nacional - LDBEN, Lei n. 9394, de 20 de dezembro de 1996.

LÜDKE, M. \& ANDRÉ, M. E. D. A. Pesquisa em Educação: Abordagens Qualitativas. São Paulo: EPU, 1986.

LUZZI, D. Educação Ambiental: Pedagogia, Política e Sociedade. In: PHILIPPI Jr, A., PELICIONI, M. C. F. (Editores). Educação Ambiental e Sustentabilidade. Coleção Ambiental, São Paulo: Manole, p. 381 400, 2005.

MARQUES, T. R. M. Interdisciplinaridade: Dificuldades e Perspectivas (Uma reflexão sobre a questão interdisciplinar na escola). Monografia (Especialização em Gestão Educacional) Universidade Federal de Santa Maria, Santa Maria, 2005. 44p.

MINAYO, M. C. (Org.) Pesquisa Social: teoria, método e criatividade. Petrópolis, RJ: Vozes, 1994.

PRINCÍPIOS DO MERCOSUL. Disponível em :http://www2.mre.gov.br/unir/webunir/bila/06/2mercosu/merco09.htm. Acesso em 05 de fevereiro de 2010.

SANTOS, S. O. Princípios e Técnicas de Comunicação, In: PHILIPPI Jr, A.; PELICIONI, M. C. F. (editores). Educação Ambiental e Sustentabilidade. Coleção Ambiental, São Paulo: Manole, p. 437 - 465, 2005.

WIKIPEDIA. A enciclopédia livre. Disponível em: www.wikipedia.com.br. Acesso em: 25 janeiro de 2010. 